
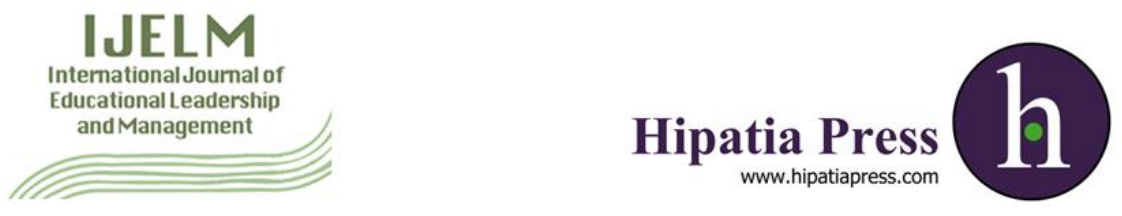

Instructions for authors, subscriptions and further details:

http://ijelm.hipatiapress.com

\title{
Building a professional learning community: a way of teacher participation in Mexican public elementary schools
}

Manuel Flores Fahara ${ }^{1}, M^{a}$ Guadalupe Rodríguez Bulnes², Magda García Quintanilla²

1) Instituto Tecnológico y de Estudios Superiores de Monterrey. Mexico

2) Universidad Autónoma de Nuevo León. Mexico

Date of publication: July $16^{\text {th }}, 2015$

Edition period: July 2015-January 2016

To cite this article: Flores, M., Rodríguez, M.G., y García, M. (2015).

Building a professional learning community: a way of teacher participation in Mexican public elementary schools. International Journal of Educational Leadership and Management, 3(2), 113-142. doi: 10.17583/ijelm.2015.1338

To link this article: http://dx.doi.org/10.17583/ijelm.2015.1338

PLEASE SCROLL DOWN FOR ARTICLE

The terms and conditions of use are related to the Open Journal System and

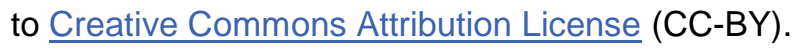




\section{Building a Professional Learning Community: A Way of Teacher Participation in Mexican Public Elementary Schools}

Manuel Flores Fahara

Instituto Tecnológico y de

Estudios Superiores de Monterrey

Magda García Quintanilla

Universidad Autónoma de Nuevo

León
$\mathrm{M}^{\mathrm{a}}$ Guadalupe Rodríguez Bulnes

Universidad Autónoma de Nuevo

León

\section{Abstract}

The professional learning communities and communities of practice approaches in the arena of education appear to hold considerable promise for sustainable school improvement. These approaches flow from the assumption that teacher's collaboration is central to transform a school into a learning organization. They also provide opportunities for teachers' professional development. The literature shows that schools are frequently called upon to improve by developing high levels of teacher collaboration. In this study we describe how the process of building a professional learning community took place in two urban public elementary schools located in Monterrey, Mexico in which seven teachers participated, from which three were novices and four experts. Through this study, we found that teachers visualized as possible the ability to generate a space where they could reflect and solve problems while they shared experiences from their teaching practices. This space of reflection also allowed them to create projects and develop a sense of community when they had more time available since the schools were usually involved in many projects. 
Keywords: professional learning communities, elementary school teachers, novice and expert teachers, professional development

\section{La Construcción de una Comunidad Profesional de Aprendizaje: Una Forma de Participación del Profesorado en Escuelas Primarias Públicas Mexicanas}

Manuel Flores Fahara Instituto Tecnológico y de Estudios Superiores de Monterrey

Magda García Quintanilla

Universidad Autónoma de Nuevo

León
$\mathrm{M}^{\mathrm{a}}$ Guadalupe Rodríguez Bulnes

Universidad Autónoma de Nuevo León

\section{Resumen}

Los enfoques de comunidades profesionales de aprendizaje (CPA) y de comunidades de práctica en educación podrían proveer oportunidades para lograr una mejora sostenible de la escuela. Dichos enfoques parten del supuesto que la colaboración de profesores es esencial para transformar la escuela en una organización de aprendizaje. A través de ellos también se pueden lograr oportunidades para el desarrollo profesional de los docentes. La literatura muestra que las escuelas son frecuentemente llamadas a mejorar a través del desarrollo de altos niveles de colaboración de los profesores. En este estudio describimos cómo se realizó el proceso de construcción de una CPA en dos escuelas primarias públicas de Monterrey. Las participantes fueron siete profesoras, cuatro expertas y tres con menos experiencia. Las profesoras visualizaron la habilidad para generar un espacio donde reflexionar y solucionar problemas, así como compartir experiencias de sus prácticas docentes. Este espacio también les permitió crear proyectos y desarrollar un sentido de comunidad al tener más tiempo. 
Palabras clave: comunidades profesionales de aprendizaje, profesores de escuela primaria, profesores novatos y expertos, desarrollo profesional

ord (1997) establishes that a professional learning community
(PLC) is one in which teachers and administrators continuously
seek and share learning, and subsequently act upon this learning. Stoll, Bollam, McMahon and Wallace (2006) explain that there is no universal definition of a professional learning community. The community may have shades of interpretation in different contexts. However, there appears to be a broad international consensus that suggests the term refers to a group of people sharing and critically interrogating their practice in an ongoing, reflective, collaborative, inclusive, learning-oriented and growthpromoting way (Mitchell \& Sackney, 2000; Toole \& Louis, 2002).

The term community of practice has been appropriated by Lave and Wegner (1991) for a particular theoretical perspective that attributes all learning to engagement in the activities of such communities. Their focus tends to be on the reproductive nature of such communities as newcomers are inducted and continue to acquire competences and status within the community.

Many authors believe that building a community contributes to school reform (Little, J.W., Gearhart, M., Curry, M., Kafka, J., 2003; Phillips, 2003; McLaughin \& Talbert, 2006). Lambert, et al (1995) and Sergiovani (1994) suggest that a new metaphor to describe schools as a community of learners has replaced the factory model that used to emphasize production and uniformity. This factory model or industrial work derived from the manufacturing industry establishes that students are taught in a similar manner to a production line. Peterson (1992) as well as Zepeda (2004) argues that our traditional approach to education is one-sided and does not address the complexity of teaching and learning and that the concept of community uncovers another possibility for understanding teachers' work. The teacher of the future will work within a professional learning community (Hargreaves, 2000; Louis \& Mark, 1998) as a creator of contextualized professional knowledge (Lewis, 2003) this occurs in a world where "education will become the centre of the knowledge society and the school its key institution" (Drucker, 1994, p. 9).

Research on the work of teachers shows that they seem to work in an isolated way (Lortie, 1975; Goodlad, 1983; Sarason, 1990; Hargreaves, 1994; Evans, 1996; Fullan, 2001). In the workplace there is a lack of 


\section{M. Flores et al. - Building a Professional Learning Community}

collegial opportunities for sharing and interaction. Schools rarely have a sharing culture which is vital to solve everyday problems more effectively. Henderson and Hawthorne (2000) indicate that, in order to become knowledge workers, teachers need to work under a supportive curriculum philosophy. This would allow them to participate in the school development knowing that they are backed up by better working conditions and a committed leadership from their principals.

In this study, we wanted to analyze how teachers from public elementary schools interacted in the process of building a learning community. We also wanted to see to what extent this space could give them opportunities for professional development as they solved problems from their teaching practice and learned from each other. In order to explore these issues, the research question that guided this study was: what happens when teachers engage in a professional learning community to improve their teaching practices?

The specific research objectives of this study were:

- To observe how seven female teachers with differences in teaching experience from two Mexican schools identified problems in their teaching practice and proposed solutions for them.

- To identify the steps that the group of teachers went through as they participated in the process of building a learning community.

- To discuss the relevance of learning communities in the development of educational environments looking for change.

Following a qualitative multiple-case study approach, the context where this study was carried out were two public Mexican elementary schools. The participants were seven female teachers who voluntarily took part in the investigation. Four of them had a wide experience while the rest (3) were beginning their teaching career.

\section{Conceptualizing a Professional Learning Community}

A review of literature about professional learning communities indicates that building a community promotes organizational learning and therefore school improvement. According to Stoll et al. (2006), international evidence suggests that the progress of educational reforms depends on teachers' individual and collective capacity and their link with school-wide capability 
for promoting pupils' learning. Building capacity is therefore critical. Developing professional learning communities seems to hold considerable promise for capacity building towards sustainable improvement.

Hord (1997) cited that there was no universal definition of a professional learning community. Based on an extensive literature review of the subject, she conceptualized professional learning communities as schools in which the professional staff as a whole consistently operates along five dimensions: (1) supportive and shared leadership, (2) shared values and vision, (3) collective learning and application of learning (formerly identified as collective creativity), (4) supportive conditions, and (5) shared personal practice.

\section{Building a community of practice}

Wenger, McDermott \& Synder (2002) define a community of practice as a group of people who share a concern or passion and deepen their knowledge and expertise in the education area from ongoing interaction with others. These communities can take many forms and may involve members from one organization or from many organizations; however, a community of practice has several characteristics which make them unique. These characteristics include: domain, community and practice. Domain creates common ground and a sense of common identity; community fosters interactions and relationship based on mutual respect and trust; while practice is a set of frameworks, ideas tools, information, language, stories, and documents that community members share (Wenger, McDermott and Snyder, 2002).

Although the concept of communities of practice has been applied to different organizations, in the field of education, according to Skalicky and West (2008), the first applications of this term have been applied to teacher training and in providing isolated teachers and administrators with access to colleagues. The perspective of communities of practice becomes therefore more relevant in the educational arena. In business, focusing on communities of practice adds a layer of complexity to the organization, but it does not fundamentally change what the business is about. In schools, however, changing the approach in which learning is achieved, is a much deeper transformation. In this article, we define professional learning 
community based on Hord's five dimensions as well as Wenger (2002) et al.'s concept of community of practice.

\section{Professional development and professional learning communities}

Because professional learning communities include teachers with diverse backgrounds, expertise and experience, they offer multiple opportunities for professional development. Learning communities place participants in situations to learn together. For instance, in a collaborative environment, expert teachers can share their expertise with novice teachers as they listen to the beginning teachers' fresh ideas. In these same communities, teachers come not only from a variety of teaching levels and disciplines, but they also share some commonalities that have to do with their teaching practice, such as an interest in creating different kinds of student assessment or accomplishing similar objectives. In this way, these learning communities engage participants in collaborative authentic tasks and roles that are linked to students' achievement.

Cordingley, Bell, Rundell and Evans (2003), through a systematic review of literature on sustained, collaborative, continuing professional development and its effect on teaching and learning, concluded that teacher collaboration improves learners' achievement. Research shows that the most productive and sustainable teacher learning communities are those not mandated by someone outside the group or formed around imposed tasks. Rather, these communities best develop organically, motivated by both social and professional forces (National Councils of Teachers of English, 2010).

A qualitative case study on practice communities was carried out in two Mexican elementary schools by González-Izasi, Castañeda-Quiroga, Torres, Banda-González, Vargas-Torres, Ruiz-Rodríguez (2013) and they found out that collaborative work has a positive impact in the studied schools, but it required a longer permanency of the actions since that type of participation was related to the school culture and demanded a considerable effort from teachers. Similar views are shared by Ezpeleta (1990) who writes that in the Mexican scenario, one of the first learning experiences of the teacher is discovering that the organization and functioning rules of the schools are considerably influential on the development of the pedagogical work. That is, teachers need to interact with the school structure (rules and hierarchies) in order to develop themselves professionally. This is something that could be in the way as they try to develop a sense of community. 
Following the definitions of professional learning communities and communities of practice as well as some of their applications, as described above, it can be said that they seem to be useful as scenarios of collaborative work where professional development of teachers and school improvement can be attained. However, this implies that teachers and administrators are willing to share and learn from one another in order to make of the school a learning community.

Public elementary schools in Mexico are part of the basic education system which consists of preschool, elementary, middle and high school. Formal education in these levels is mandatory and provided by the State (Federation, States, Federal District and municipalities) throughout the country under the terms of Article III of the Political Constitution of Mexico. Primary schools thus work following a centralized national educational model implemented throughout the country which includes a common curriculum, calendar of activities and projects. This centralized nature in the primary school system brings benefits as to a standardized instruction, yet it also brings challenges such as increasing coverage, and adapting education to the different needs, interests and abilities of the population. Thus the idea of working with teachers in primary schools to see how they organized themselves around a common project in order to improve their practice was an objective central to our study. We wanted to see how the ideas proposed by the concepts of learning communities worked among the professionals of education and perhaps give them a chance to experience collaborative work as a way of improving their practice.

We believe that this study is important because it connects theory to practice. The inquiry involves researchers and teachers in a research process. Teachers build a learning community according to the needs of their teaching practice and create their own project while researchers analyzed how the process of building a learning community was given. Therefore, the experience of teachers building such community showed the research team how a learning community could develop.

\section{Method}

\section{Context and participants}


The contexts in which the study was conducted were two urban public elementary schools in Monterrey, Mexico, during the 2010-2011 academic years. The participating schools could be considered middle size as they had more than 300 students each. The first school, which we call A, is located at the south of the city in a middle class area with 360 students and 24 teachers. School B has a similar socio-economic background and a population of 480 students and 21 teachers. The study participants included seven voluntary female teachers (4 in school A and 3 in school B) and two principals (female in school A; male in school B) whose professional experience varied. This difference in years of experience was used to classify them as expert or novice. (See Table 1).

Table 1.

Participants' profile

\begin{tabular}{lcllc}
\hline Teacher & School & Gender & Experience & Grade being taught \\
\hline Imelda & A & Female & Novice & 4 th \\
Gloria & A & Female & Novice & $1 \mathrm{st}$ \\
Ruth & A & Female & Expert & 6 th \\
Emilia & A & Female & Expert & 5 th \\
Alejandra & B & Female & Novice & $2 \mathrm{nd}$ \\
María & B & Female & Expert & 5 th \\
Alicia & B & Female & Expert & 4 th \\
\hline
\end{tabular}

The process to select the sample in this study was what Sandelowski (2007) calls a purposeful sampling strategy in which the researchers determine the adequate sample size depending on their judgment and experience in evaluating the quality of the collected information against the purpose of the research and the intended research product. According to Álvarez-Gayou (2003), in qualitative analysis all scenarios and informants are considered valuable sources of data since they are both similar and unique at the same time. They are similar in the sense that in any given context one can identify features of general social processes. They are unique since in each scenario or in each informant the different aspects of 
social life are better highlighted and therefore can be studied more in depth. This is the case of the sample used in this research and which could be commonly found in several other public Mexican elementary schools.

In terms of resources, they seemed to be limited in the participating schools. In both cases the physical infrastructure did not include a place where teachers could meet, such as a teachers' area or meeting room. This led to improvising a meeting place for researchers and teachers to conduct work sessions. In school A, for example, researchers and teachers met in a computer lab which was free at the time of the meetings. In school B, meeting space was located in an old sort of "library" where the school staff kept books and materials used in school ceremonies. There was not a space allocated specifically for teachers to meet and work outside the classroom.

\section{Research approach}

The methodology in this study followed the multiple case study analysis approach (Stake, 2006). This research design is suitable to study the same phenomenon through various cases that are organized around at least one research question. Following this approach allowed the researchers to generate a detailed description and rich understanding of how the professional learning community process took place in the two urban public elementary schools. The two cases (school A and school B) were similar in some ways - school size, context, socioeconomic status of students and roles of teachers and principals. However, each school could be considered unique in this study as a complex entity due to its own situation and particular context or background. An important characteristic to emphasize in this approach was that it allowed the researchers to be involved in the schools assuming the role described by Wolcott (1997) as a privileged observer, someone who is known and is given easy access to information from the field. Spradley (1980) describes this type of participation as moderate where the researcher combines times in and out of the site being observed. In this study, we participated as insiders in the teachers' community while carrying out the investigation as outsiders.

As researchers we were interested in studying this topic because we believe that educational change can come through the collaboration of teachers and framing this into the idea of a learning community seemed very valuable. Another important reason was that one of the main topics in our 
research team agenda is professional development and this study could give us some ideas as to how it is given among teachers in a learning community.

\section{Instruments}

Data for this research was collected through different instruments: semistructured interviews, participant observation, field notes, and recordings and transcriptions of the teachers' conversations during the meetings.

The main instrument used in this study was participant observation. Stake (2006) points out that the case study researcher needs to generate a picture of the case and then produce a portrayal of the case for others to see. He also states that the most meaningful data gathering methods are often observational, both direct observation and learning from the observation of others. Regarding this, Lincoln and Guba (1985) say that in situations where motives, attitudes, beliefs, and values direct much, if not most of human activity, the most sophisticated instrumentation researchers possess is still the careful observer: the human being who can watch, see, listen to questions, probe, and finally analyze and organize his or her direct experience.

The observations were conducted in situ (School A and B) by both researchers and research assistants. The research assistants were two students with a Bachelor of Arts degree in education from the Universidad Autónoma de Nuevo León and one with a Master's of Arts in Education from the Tecnológico de Monterrey. The assistants were trained by the researchers to conduct these observations. The training consisted of explaining how to establish rapport and communication with the teachers participating in the study and how to record field notes from the events and teachers' conversations. The recording of data was done following an observation guide adapted from Merriam (2009), as shown in Table 2.

Table 2.

Observation guide (adapted from Merriam, 2009)

1. The participants: mood, attitudes, disposition, resistances, willingness, roles characteristics.

2. Activities and interactions: types of activities, agreements, points of view.

3. Conversations: types of conversations about the teaching practices, experiences. 
4. The physical setting: tables and chair arrangements.

5. Research behavior: attitudes roles.

Throughout the investigation, researchers and their assistants (research team) worked together to face a reality in the schools that was unknown to them. This was due to the uncertainty and ambiguity found in situations where the researchers were both an outsider and insider at the same time. In this case, for example, none of the members of the team belonged to the schools. As previously pointed out, according to Spradley's levels of participant observation (1980), observers in our study sustained a moderate participant observation in which they took part in the process and made observations about it at the same time. The results of these observations were recorded as researchers' notes.

As a complement to the observations using questions to guide conversations, the research team also used semi-structured interviews with participants (teachers willing to participate in the study) as well as with nonparticipant teachers (those who refuse to take part in the whole project). Questions from the interviews acted as guides to motivate and generate more information and data from teachers (Rubin and Rubin, 2012).

Each semi-structured interview was recorded and generally lasted approximately 45 minutes. The interviews with the teachers focused on their views about becoming a community, ways to learn and share, use of knowledge, impressions and perceptions about their participation in the learning community as well as reasons for participating or not in such community. The interviews with the participating teachers were conducted in the middle as well as at the end of the process. Interviews with nonparticipating teachers were used to gather their reasons to refuse participating and their views on the creation of a professional learning community. Since the interaction with these teachers was somehow limited, the interviews were in the form of a conversation and informal dialogue.

\section{Research Procedure: The Process of Building a Professional Learning Community}

Roberts and Pruitt (2009) note that it is difficult to provide a cookbook recipe to describe how to initiate the transformation of a school into a 
learning community. Every school is different. Every faculty is different. Therefore the process of becoming a professional learning community could not be presented in the form of a recipe. In the case of this study, teachers from Schools A and B as well as the research team went through five different stages to build a professional learning community as described below:

First Stage: Approaching the school. The selection of schools was done according to the following criteria: To participate in this project teachers and principals had to be interested in improving their school. Another criterion was that the schools had to have an average profile, that is, they had to share similar characteristics (size, socioeconomic background, urban location) in order to allow the researchers to observe how the process might develop in the majority of the public elementary schools. In this stage, the principal and the teachers were presented the project and they had to express their willingness to participate in the study. The principal's support on this was crucial since it was the first door to be opened to approach the school.

Second Stage: Introducing the project to the teachers and administrators. Once the schools agreed to participate, the researchers presented the project to teachers and administrators. The first meeting with the teachers consisted of an explanation of the project and the roles and responsibilities of each of the participants involved. During this meeting, reactions varied, some of the teachers agreed with the project while others showed strong disagreement as they considered participation an additional burden. Their response mainly related to being involved in many projects organized by the Ministry of Education and therefore they felt they did not have enough time for the project being presented. Those teachers who responded positively to the proposal and voluntarily agreed to be part of the project started forming working groups whose initial task was to identify a problem in their teaching practice. This willingness to participate voluntarily is one of the main principles observed when building learning communities.

Third Stage: Teachers' projects. Each school decided to work on a project based on the needs of their context and in their interest in improving specific areas of their teaching practice. Thus, teachers from school A selected to work on the issue of teaching and learning strategies to enhance the cognitive learning of their students. Teachers from school B decided to work on reading comprehension strategies to help the general learning of students. 
Fourth Stage. Starting the project. To begin the project, it was necessary to discuss and decide the roles of researchers, research assistants, and teachers. Another important issue was deciding on the schedule and place for the working meetings. Finally, the participants designed the structure of the sessions and the schedule to be followed for over a period of six months. In each school, sessions lasted approximately one hour and they were programmed during regular school hours. During the time when the meetings were held, research assistants, and in some cases, some students' parents would volunteer to come and work with the teachers' groups on tasks previously assigned. This proved positive as a way to start creating a sense of community in the school.

Fifth Stage. Implementing the teachers' projects. The implementation of the teachers' projects is presented in four different phases as shown in Table 3. This way of organizing the phases follows a model derived from different views from organizational learning (Di Bella \& Nevis, 1998; Lee \& Kim, 2001; Senge, 1990/ 2000; Wenger, 2001). These models commonly organize learning in four stages: acquiring, sharing, using and disseminating knowledge.

Table 3.

Phases of teachers' projects implementation in Schools A and B

\begin{tabular}{|c|c|c|c|c|}
\hline \multirow[t]{2}{*}{ Schools } & \multicolumn{4}{|c|}{ Phases } \\
\hline & $\begin{array}{c}\text { acquiring } \\
\text { knowledge }\end{array}$ & $\begin{array}{c}\text { sharing } \\
\text { knowledge }\end{array}$ & $\begin{array}{c}\text { using } \\
\text { knowledge }\end{array}$ & $\begin{array}{l}\text { disseminating } \\
\text { knowledge }\end{array}$ \\
\hline $\begin{array}{c}\text { School } \\
\text { A }\end{array}$ & $\begin{array}{l}\text { Teachers acquired } \\
\text { knowledge about } \\
\text { cognitive teaching } \\
\text { strategies. }\end{array}$ & $\begin{array}{l}\text { Teachers shared } \\
\text { what they knew } \\
\text { about strategies as } \\
\text { they incorporated } \\
\text { new content } \\
\text { knowledge. }\end{array}$ & $\begin{array}{l}\text { Teachers put into } \\
\text { practice learning } \\
\text { strategies } \\
\text { previously shared } \\
\text { in the meetings } \\
\text { reporting on their } \\
\text { experiences. }\end{array}$ & $\begin{array}{l}\text { In order to disseminate } \\
\text { knowledge, a portfolio } \\
\text { in CD format was } \\
\text { prepared with all the } \\
\text { successful strategies } \\
\text { tested in the } \\
\text { classroom. }\end{array}$ \\
\hline $\begin{array}{c}\text { School } \\
\text { B }\end{array}$ & $\begin{array}{l}\text { Teachers acquired } \\
\text { knowledge about } \\
\text { how to engage } \\
\text { students into } \\
\text { reading }\end{array}$ & $\begin{array}{l}\text { Teachers shared } \\
\text { opinions about } \\
\text { issues concerning } \\
\text { reading } \\
\text { comprehension: }\end{array}$ & $\begin{array}{l}\text { Teachers } \\
\text { implemented a } \\
\text { program called } \\
\text { "Adopting a } \\
\text { reader" ("Adopta }\end{array}$ & $\begin{array}{l}\text { The dissemination } \\
\text { knowledge was done } \\
\text { through a Book Fair } \\
\text { (Feria del libro) and a } \\
\text { live Story Teller }\end{array}$ \\
\hline
\end{tabular}




$\begin{array}{llll}\text { comprehension } & \text { problems, } & \text { un lector") where } & \text { session. These } \\ \text { strategies through } & \text { strategies and } & \text { students would } & \text { experiences were } \\ \text { literature about this } & \begin{array}{l}\text { alternative } \\ \text { topic. }\end{array} & \text { read to each other } & \text { recorded in video. } \\ \text { solutions. } & \text { taking turns. } & \end{array}$

In order to build trustworthiness from data gathered, the research team used the following three techniques for addressing credibility or accuracy of information: (1) triangulation of data, (2) member checking, and (3) peer debriefing (Erlandson, Harris, Skypper \& Allen, 1993; Lincoln and Guba, 1985). We triangulated data, for example, the results of participation observations from the process of learning communities, and interviews with participant and non-participated teachers. Also we used member checking at the end of each interview, sharing a synthesis of the teachers' responses to the interview with participants. Finally, we incorporated peer debriefing by inviting other colleagues who had not participated in the research to provide feedback on the method, process, and findings.

\section{Data analysis}

In order to analyze data we used the constant comparative method of analysis (Glaser, 1978). This analysis followed a process of inductive and open coding to allow for categories of analysis to emerge from the data as the analysis was done (Miles and Huberman, 1994). Categories were generated to organize and make sense of specific information. Finally, categories were examined for significant patterns and for redundancy and overlapping. The process of comparison of categories was implemented after the saturation factor was achieved. After this, the research team arrived to the categories discussed in the results section.

\section{Results}

In this study the researchers carried out the reconstruction of research notes and analysis from observations and semi-structured interviews. The following categories emerged from the data:

- Attitudes towards introducing a new project in the school.

- Expertise exchanges between novice and experts teachers. 
- Recognizing the significance and worth of a professional learning community.

The following table summarizes the attitudes we observed in teachers when they were invited to participate in the new project.

Table 4.

Category: Attitudes towards introducing a new project in the school

Subcategories

- Time constraints

- Work overload

- Freedom to develop a project

- Encourage other teachers to participate

\section{Voices of teachers}

It is good to have many ideas from colleagues; the problem is that there is no time (field note, nonparticipant teacher).

The trouble is that we have many projects and activities, sometimes we cannot finish the program with everything we have (field note).

I liked asking for opinions of what we wanted to work, because we (usually) do projects suggested by somebody else (interview Alejandra, novice teacher).

We invited teachers who had not been in the team to integrate in this project (interview, Emilia, expert teacher)

Attitudes towards introducing a new project in the school. One of the first objectives was the voluntary willingness of the educational community to take part in the study. Unfortunately, in a school system designed on industrial work principles in which individuals seem to be in a production line (school grades, in this case) with little space given for interactions (work between groups from different levels), this was not always easy. As explained by Hargreaves and Fullan (1996), the complex organizational structure mitigates efforts to build whole-school learning communities. These structures often block efforts to bring about the changes that promote the shift to a collaborative culture and the building of community (Senge et al., 2000). 
Louis and Kruse (1995) state that there are five structural conditions essential for establishing a professional learning community. The structural conditions are (1) providing adequate time for teachers to meet and exchange ideas; (2) locating teachers physically close to one another so that they can observe and interact with peers; (3) ensuring teacher empowerment and school autonomy so that teachers feel free to do what they believe to be best for their students; (4) creating school-wide communication structures, including regularly established meetings devoted to teaching, and other professional issues; and 5) employing methods, such as team teaching, that requires teachers to practice their craft together.

Although this could be true for most scenarios, and the conditions in the schools where the research team worked were not much different from most schools, the introduction of a new project brought out different attitudes from the participant teachers. Some were willing to embark on that project, while others remained hesitant; some eventually declined the invitation. The answer of most of the teachers was: "We do not have time for working with you". In this regard, Collinson and Cook (2001) point out that time is one of the greatest constraints to any change process. However, finding more time for teachers by reallocating time within a fixed schedule has not brought about desired reforms. The Collinson and Cook study (2001), like many before it, indicated that time is a major barrier to teacher learning and school change. Unlike other studies, however, this study explored what teachers mean when they talk about time. The teachers' interpretation indicated that time for them was multifaceted, complex, dynamic, and nonlinear. Until now, suggestions for providing time for teacher learning have generally represented a reallocation of time within a fixed schedule and have reflected a uniform conception of time. To facilitate this, the existing research suggests that the school needs to be organized to allow time for staff to meet and talk regularly (Louis et al., 1995). Time is critical for any nonsuperficial learning (Stoll \& Fink 1996).

At the beginning, it was not easy for the researchers to introduce the Project in both schools. In general, there was a feeling of resistance towards engaging in a new project. The reasons that the teachers gave were that they already had too many projects from the Department of Education, and that it was a demanding work. This finding is supported by Hargreaves and Goodson (2006:3) who established that: 
In this age of standardization and marketization, the aging boomer cohort has become increasingly cynical about successive, accelerating waves of contradictory reforms that have culminated in systems of standardization that are eroding teacher autonomy, narrowing the curriculum, and undermining the idea of teaching as a broader social mission.

This may explain to some extent, the teachers' readiness to reject what they called "just another project". The literature suggests that teachers resist doing whatever is being proposed because they want to cling to their old ways (Richardson, 1998). Even Pete Seeger, a champion of social change for almost 70 years, acknowledges that his first response to the prospect of change is resistance. The view of the teacher as reluctant to change is strong and widespread, and it is one the researchers have heard expressed by many teachers as well. It is promulgated by those who think they know what teachers should be doing in the classroom and are in a position to tell them what to do (Richardson, 1998). One of the non-participant teachers expressed this by saying: "If we participate, soon they will institutionalize the project and then we will have more work to do." (Field note)

Roberts and Pruitt (2009) state that many challenges for schools are associated with shifting from a traditional or industrial model to a professional learning community model which is centered in knowledge and learning. Essentially, the shift to a learning community model requires a change in the culture of a school. School culture has been defined as "the set of norms, values and beliefs, ritual and ceremonies, symbols and stories that make up the -persona- of the school" (Peterson, 2002, p.10). This shift requires new outlooks and behaviors, as learning-community schools call for teachers to examine what they believe about their teaching practices (Roberts and Pruitt, 2009).

The following category analyzed was about the exchanges of expertise given in the interactions novice and expert teachers had while planning and carrying out their project.

Table 5 .

Category: Expertise exchanges between novice and expert teachers

Subcategories

- Learning from other
Voices of teachers

I am here and I learn from everybody something 


\section{Subcategories Voices of teachers}

teachers

- Sharing practices useful for my academic background (field note, Imelda, novice teacher).

If I can help in anything is to share and help among ourselves (interview, Alicia, expert teacher).

I placed three students in cooperative teams to make a project like you suggested to me, and it is effective (field note, Gloria, novice teacher).

I promise to do my lessons planning according to the model and share it all with you (field note, María, expert teacher).

Expertise exchanges between novice and experts teachers. This category appeared frequently through in-depth interviews as well as in the meetings between researchers and teachers, in both schools. Expertise exchanges, also called reciprocal teaching by Lemlech and Hertzog (1999), refers in this paper to an activity that took place in the form of a dialogue between experienced and less-experienced teachers in which they shared their best teaching practices. Teachers recognized that the meetings offered a good opportunity to know what was going on in other classrooms. During these meetings, teachers had the chance to share classroom management strategies, ways of checking attendance and tracking homework, as well as teaching techniques. An enthusiastic teacher expert shared a class format which was regarded by his colleagues as an excellent resource. This format was later modified and enriched by teachers according to their needs (Field note).

A novice teacher asked an experienced teacher about ideas for teaching mathematics. The latter suggested the following strategy:

I think it's easy and practical teaching mathematics to the whole class using the blackboard. Then I have students learn more individually, working with their books and notebooks. I typically explain and give feedback to my students in those specific steps that they do not understand. (Note from interview) 
New teachers also provided fresh ideas to colleagues. For example, a novice teacher who had read Vygotsky suggested that students could read short stories, poems, and legends to each other in pairs, rather than listening to the teacher.

Novice teachers recognized that they required support from experienced teachers on tasks such as lesson planning, classroom discipline, learning strategies, content selection, and evaluation of the curriculum (Lemlech and Hertzong, 1999). In the organizational learning model proposed by Senge (1990), this recognition is identified as a personal domain.

In the novice - experienced teachers category, collaboration appears between teachers from Schools A and B as they communicate, learn, share and use knowledge from their peers. Teacher collaboration in Mexico is indeed promoted in schools by the Ministry of Education; however, Jiménez and Jiménez (2004) point out that despite the efforts of the Ministry of Education to foster collaboration within schools, many currently exist in professional isolation. This is sometimes caused by the school organization itself or by teachers' personal factors, such as attitudes, beliefs and expectations which may inhibit them in sharing their knowledge and experiences, and enriching themselves through collaborative processes. Also Chacón (2005) mentions that in Mexico, teaching practices of elementary school teachers occur in an environment of loneliness and routine. That is, only the individual teacher knows what is going on in his or her classroom and they usually keep what happens to themselves. Teachers need to learn to share their experiences and knowledge with their peers. They also need to learn from each other as they live together academically. It is only in this way that they will improve their practice.

Research suggests that collaboration among teachers in Mexico is a key factor in the process of change, innovation, and educational improvement, as it provides compatibility and complementarity among professionals. Such findings were pointed out in a research project conducted in various states of Mexico in which 201 schools participated during the 1997-98 school year (Bonilla, 2001).

International evidence (Stoll et al., 2006) points out that progress in educational reform depends on teachers' individual and collective capacity to promote pupils' learning, as well as on teachers' involvement with the school-wide organization. Furthermore, Stoll et al. (2006) suggest that 
understanding effective Professional Learning Communities (PLCs) in schools as well as researching their existence, operation, and effectiveness is at a relatively early stage of development in many countries. However, evidence demonstrates that PLCs have a positive impact on school improvement, and thus building their capacity is critical.

It is important to address that an effective system of teacher collaboration within a professional learning community does not emerge spontaneously or only by invitation. It is important to cultivate high-quality collaboration. For Gajda and Koliba (2008), this is an essential element of substantive school change which is the principals' responsibility.

The last table here shows the ideas found in the discourse of teachers about the value and significance of a learning community. Here is where their opinions were highly important for us as researchers since this is where they evaluated their experience and we could see it had been a positive one.

Table 6.

Category: Recognizing the significance and worth of a PLC

Subcategories Voices of teachers

- The project helps Work sessions were very good. There was freedom and we us with work could make suggestions. From there (the sessions), the suggestions of adopting a reader project came up (interview, Gloria, expert teacher).

- Feelings of support

The situation got better; it was an enriching and innovative

- Has impact in the experience (interview, Imelda, novice teacher). classroom

We saw the work that we did was more helpful than the workload implied (interview, Emilia, novice teacher).

- Enrich the teaching practice It is willingness to do things. It is no exclusive to this school, because any school can have and develop this project (field note, María, expert teacher).

- A freedom space I am very happy with the results of the reading project and I would like to invite my colleagues to join this type of projects because it helps us improve our work in the classroom.

The work we did was seen more as a way to support us rather than being an extra burden. We always felt supported in what 


\section{Subcategories Voices of teachers}

we needed when we worked as a team (field note).

Recognizing the significance and worth of a professional learning community. Once the project was accepted and the research team began having meetings with the teachers, they recognized that the weekly meetings provided them with a space to share ideas and talk in a caring and reflective atmosphere. Teachers began to understand a learning community. Zepeda (2004, p. 148) notes the importance of dialogue in studies with groups of teachers: "the opportunities for teachers to talk helped 'glue' the learning community together."

On a similar matter, Levin \& Rock (2003) pointed out that teacher educators have found that when both novice and experienced teachers work collaboratively, both groups become more reflective, critical, and analytical of their teaching behaviors. With time, they may develop a sense of pedagogical partnerships or community "because they have the opportunity to engage in shared dialogue and critical inquiry" (p. 136).

In this study the teachers expressed how good it had been to have a time out of class to meet and talk about what they were doing in their classrooms. Ruth, one of the teachers said:

I found the workshops very good. I liked that we had the opportunity to speak freely and give our opinions. It was exactly this work environment that allowed us to have the initiative to create one of the reading projects. (Interview)

Zepeda (2004) points out how dialogue is vital to building learning communities. In his studies he found that opportunities to talk and dialogue helped the learning community persist. Dialogue serves as 'glue', as mentioned by Zepeda metaphorically, to keep the group together and to gradually create that sense of community. In the words of teacher Ruth, who positively perceived the value of the meetings as allowing the teachers to share ideas, this time outside the class allowed also to "speak freely and give ...views". This brings up the repressive conditions under which these teachers may be working. Learning communities require conditions that 


\section{M. Flores et al. - Building a Professional Learning Community}

create a different space in which teachers feel free to express their views and discuss their problems they face in the classroom.

Although not explicitly mentioned in the interviews, it is clear that the work environment or school structure under which there is limited communication and infringing freedom of expression of teachers is one of the obstacles to the development of these learning communities. Lortie (1975) confirms that teachers continue to work in isolation in many work environments in schools. No wonder, then, that the teachers involved in this study found the meetings valuable as an opportunity to grow personally and professionally.

Another positive aspect of the professional learning community is the reflection process that occurs in a group where there are teachers with different levels of experience. Experts have found that when you combine a group of inexperienced teachers with those who are most experienced in the profession, both groups become more reflective, critical, and analytical of their own classroom practices. Over time, the group develops a sense of community and partnership teaching (Levin and Rock, 2003) because in these communities teachers have the opportunity to dialogue and engage in critical reflection of their actions. This is part of the group potential of a learning community. Young teachers and teachers who have extensive experience benefit one another in this work environment. Gloria, who has a few years in teaching, said:

Among the objectives of the project, I remember one of them was to enrich our teaching practice by sharing our experiences with other teachers, reflecting on our teaching practice and our role as part of a learning community. (Interview)

Meanwhile, Emilia, a teacher with many years of experience mentioned:

The activities we did with the reading project had an impact on other areas of our teaching practice. For example, it improved the interaction among students in the classroom. (Field note)

During the project, the research team realized that the traditional idea that teacher "experts" (based on years of teaching) are always in a position to teach those who are new to teaching is changing. We noted that Alejandra, 
the youngest teacher in the community became the leader of the group and proposed most of the ideas for various projects in and outside the classroom, such as "La feria del libro en la escuela", [School book fair], the participation of a storyteller, and "adopt a reader," one of the most popular among students. In this activity, students read a story to one another, regardless of their grade-level. The traditional view that more experienced teachers teach novice teachers in this study was reversed as the youngest teacher demonstrated leadership and skills to a group of teachers who had more experience.

During the development of the projects chosen by the teachers in the schools, the teachers themselves recognized the importance of synergy among them to carry out these projects and learn from each other. Maria, the teacher with the most experience in the group explained:

The work we did was seen more as a way to support us rather than being an extra burden. We always felt supported in what we needed when we worked as a team. (Field note)

Gloria put it as follows:

I am very happy with the results of the reading project and I would like to invite my school colleagues to join this type of research project because it helps us improve our work in the classroom. (Interview)

From the perspectives and experiences reported by the teachers in this study, the research team concluded that collegial work in schools is absent and, therefore, at the beginning of the project both teachers and administration were resistant to participate in a learning community. It has been also possible to visualize how the teachers throughout the project engaged in activities that lead them to see themselves as a community and declare that these spaces are useful for professional growth.

\section{Discussion and Final Reflections}

The findings reported here suggest that building learning communities in Mexican elementary public schools is promising, although there are still some problems to overcome. Despite the fact that teacher participation in 


\section{M. Flores et al. - Building a Professional Learning Community}

learning communities is completely voluntary, according to observations made by the research team, a good number of teachers and administrators are still reluctant to participate. The reasons they give are usually related to time constraints, since the school is involved in many projects and they feel overwhelmed. Up to this point and considering other studies in similar contexts (Flores \& Flores, 2005; Flores, Flores \& Garcia, 2006), it is possible to conclude that school structure is partly responsible for limiting teachers' participation and integration in a learning community. However, those teachers who are willing to participate have an opportunity to discover a friendly space to learn, to reflect, and to identify and solve problems while they share experiences to improve their own teaching practices.

Through this project teachers acknowledged the fact that they learned from their peers. They also saw that the learning community was an opportunity for novice teachers to learn from expert teachers and vice versa. In this way the process allowed teachers to create projects together and experience a sense of community.

In the field of education, building a learning community could be considered an alternative for teachers' professional development and as a way to promote educational changes. This alternative, however, brings with itself some challenges to be faced. One of these challenges could be the organizational structure, or the way the school organizes teachers' activities in and outside the classroom, participation in committees and school work, in general. This type of school structure may not allow teachers to fully participate and learn from one another in a learning community due to school commitments. Nevertheless, as found in this study, even within this structure, for those teachers willing to participate, it was possible to find a space where they could share their teaching experiences, identify problems and share ideas to solve them as a group.

The teachers who participated in this project agreed that sharing their experiences had been enriching for their professional development. It became evident that for the less experienced teachers, what the expert teachers shared in those meetings was useful not only professionally but also for personal reasons. Acknowledging the abilities and knowledge of others in the group is what Senge (1990) calls "personal domain". In this case, the explicit knowledge and expertise that the experienced teachers had gained in their profession and that had been tested in their teaching practice was acknowledged by the novice teachers. They also evaluated as positive the 
fact that these expert teachers were sharing these experiences with them in an environment which allowed for the exchange of ideas, strategies and ways of solving teaching problems. In such an environment, this type of exchange among teachers went from sharing professional expertise to a more personal level as they talked about their interest in students' general improvement and their personal commitment to their profession.

This sharing of experiences could be considered, at some point, as a second step in their professional education, in addition to what they learned in the School of Education (Normal School). In this sense, learning in a community proves to be a viable way for professional development. It is a chance to learn in and from their teaching practice. It is a win-win relationship where both novice and experienced teachers gain knowledge and expertise. The fresh ideas from the first may bring new knowledge to the latter.

Another issue that emerged as part of the study was the time constraint teachers have due to their busy schedules. According to some teachers' opinions, this stops somehow their willingness to engage in new projects and initiatives. This time constraint is perceived by the teachers in an objective as well as in a subjective way. In the words of Hargreaves (1994) this constitutes for teachers subjectively conceived possibilities as well as limitations.

The results reported in this study reveal that there are benefits and challenges to face if one is to engage in building professional learning communities among teachers. It also made the researchers think about ways to investigate how these communities could be implemented in schools as a way to organize the work of teachers since they offer opportunities for professional as well as personal development. An alternative scheme to overcome the problem of time constraint could be to create online communities which offer opportunities to interact, exchange, document and generate local and contextualize knowledge.

In times in which educational change values teamwork and professional networking, it seems relevant to continue researching how promising professional learning communities could be for teachers and their professional development. They can work as an alternative for different purposes such as: promoting better working conditions to allow teachers time to work in teams and develop projects; working towards the benefit of 
the students' learning and the school improvement and encouraging teachers to learn from each other as they strive for their own growth.

\section{References}

Álvarez-Gayou, J.L. (2003). Cómo hacer una investigación cualitativa. Fundamentos y metodología. México: Paidós Educador.

Bonilla, R. (2001). La gestión en la escuela primaria. Revista Educar, 16.

Cámara, C. G. (2010). Un cambio sustentable: La comunidad de aprendizaje en grupos de maestros y alumnos de educación básica. Perfiles Educativos. 32(130), 122-135.

Chacón, P. A. (2005). La formación inicial de profesores de educación básica en México. Observatorio Ciudadano de la Educación, 190, Retrieved from http://www.observatorio.org/colaboraciones/chacon2.html

Collinson, V., \& Cook, T.F. (2001). "I don't have enough time": Teachers' interpretations of time as a key to learning and school change. Journal of Educational Administration, 39(3), 266-281. doi: 10.1108/09578230110392884

Cordingley, P., Bell, M., Rundell, B. \& Evans, D. (2003). The Impact of Collaboration CPD on Classroom Teaching and Learning. In: Research evidence in education library, version 1.1. London: EPPI-Centre, Social Science Research Unit, Institute of Education.

Di Bella, A. J., y Nevis, E. C. (1998). How organizations learn: An integrated strategy for building learning capability. San Francisco, CA: JosseyBass.

Drucker, P. (1994). The age of social transformation. The Atlantic Monthly, (Nov), 1-19. $\quad$ Retrieved from http://www.theatlantic.com/issues/95dec/chilearn/drucker.htm

Erlandson, D. A., Harris, E.L., Skypper, B.L., Allen S. D. (1993) Doing naturalistic inquiry: A guide to methods. Newsbury Park, CA: Sage.

Evans, R. (1996). The human side of school change. San Francisco, CA: JosseyBass. 
Ezpeleta, J. (1990). El Consejo Técnico: Eficacia pedagógica y estructura de poder en la escuela primaria mexicana. Revista Latinoamericana de Estudios Educativos, 20(4), 13-33.

Flores Kastanis, E., Flores Fahara, M., \& Garcia, Q. M. (2006). The effects of the school structure on organizational learning: A multiple-case study from a collaborative research project in northern México. Paper presented at the Annual Meeting of the American Educational Research Association, San Francisco, CA.

Flores Kastanis. E., \& Flores Fahara, M. (2005). Public school as learning communities. A multiple case study of collaborative research in Northern Mexico. Paper presented at the Annual Meeting of the American Educational Research Association, Montreal, Canada.

Ford (1995). The constructivist leader. New York, NY: Teachers College Press. Fullan, M. G. (2001). The new meaning of educational change. (3rd ed.). New York, NY: Teachers College Press.

Gajda, R., \& Koliba, C. J. (2008). Evaluating end improving the quality of teacher collaboration. NASSP Bulletin. 92(2), 133-153. doi: 10.1177/0192636508320990

Glaser, B. (1978). Theoretical sensitivity: Advances in the methodology of grounded theory. Mill Valley, CA: Sociology Press.

Gonzalez-Izasi, R.M., Castañeda-Quiroga, F.A., Torres, M., Banda-Gonzalez, R., Vargas-Torres, R.C., \& Ruiz-Rodríguez, F. (2013). Colaboración en comunidad de práctica para el desarrollo profesional. Pixel-Bit. Revista de Medios y Educación, 42, 103-113.

Goodlad, J. I. (1983). The school as workplace. In G. A. Griffin (Ed.), Staff Development (pp. 36-61). Chicago: The University of Chicago Press.

Hargreaves, A. (1994). Changing teachers, changing times: Teacher work and culture in the postmodern age. New York, NY: Teachers College Press.

Hargreaves, A. (2000). Four ages and professional learning. Teachers and teaching. History and Practice, 6(2), 151-82. doi: 10.1080/713698714

Hargreaves, A. \& Fullan, M. (1996). What's worth fighting for in your school. New York, NY: Teachers College Press.

Hargreaves. A., \& Goodson, I. (2006). Educational change over time? The sustainability and non-sustainability of three decades of secondary school change and continuity. Educational Administration Quarterly, 42(1), 3-41. doi: 10.1177/0013161X05277975 
140 M. Flores et al. - Building a Professional Learning Community

Henderson, J.C. \& Hawthorne, R. D. (2000). Transformative curriculum leadership. River, N.J: Prentice Hall.

Hord, S. M. (1997). Professional learning communities: Communities of continuous inquiry and improvement. Austin, TX: Southwest Educational Development Laboratory.

Jiménez, C. A, and Jiménez, E. (2004). Colaboración entre docentes para promover el aprendizaje del lenguaje en la primaria. Revista Iberoamericana de Educación. Retrieved from http://www.rieoei.org/deloslectores/593Jimenez.pdf

Lambert, L., Walker, D., Cooper, J.E., Lambert, M.D., Gardner, M. E., \& Slack, P. Jord (1995). The constructivist leader. New York, NY: Teachers College Press.

Lave, J. and Wenger E. (1991). Situated learning: Legitimate peripheral participation. Cambridge: University Press. doi: 10.1017/CBO9780511815355

Lee, J. H., and Kim, Y G. (2001). A stage model of organizational knowledge management: a latent content analysis. Expert Systems with Applications. 20, 299-311. doi: 10.1016/S0957-4174(01)00015-X

Lemlech, J.K., \& Hertzog, H.H. (1999). Reciprocal teaching and learning: What do master teachers and students teachers learn from each other? Paper presented at the Annual Meeting of the American Educational Research Association, Montreal, Canada.

Levin, B., \& Rock,T. (2003). The effects of collaborative action research on preservice and experienced teacher partners in professional development schools. Journal of Teacher Education, 54(2), 135-149. doi: 10.1177/0022487102250287

Lewis, M. (2003). The dynamics, implications and effects of knowledge creation in professional learning communities: Three case studies. (Unpublished PhD Dissertation).University of Southern Queensland, Toowoomba, QLD

Lincoln, Y. S., \& Guba, E.G. (1985). Naturalistic inquiry. Newsbury Park, CA: Sage.

Lortie, D. C. (1975). Schoolteacher: A sociological study. Chicago: University of Chicago Press.

Little, J.W., Gearhart, M., Curry, M., Kafka, J. (2003). Looking at student work for teacher learning, teacher community and school reform. Phi Delta Kappan, 85(3), 184-192. doi: 10.1177/003172170308500305 
Louis, K.S., \& Marks, H. (1998). Does professional community affect the classroom? Teachers'work and student experiences in restructuring schools. American Journal of Education, 106(4), 532- 75. doi: $10.1086 / 444197$

Louis, K.S., Kruse, S., \& Bryk, A.S. (1995). Professionalism and community: What is it and why is it important in urban schools? In K. S. Louis, S. Kruse \& Associates (Eds). Professionalism and community: Perspectives on reforming urban schools. (3-22). Long Oaks, CA: Corwin.

McLaughlin, M.W., Talbert, J. E. (2006) Building school-based teacher learning communities: Professional strategies to improve student achievement. New York: Teachers College Press.

Merriam, S. B. (2009). Qualitative research and case study applications in education. San Francisco, CA: Jossey Bass.

Miles, M. B., \& Huberman, A. M. (1994). Qualitative data analysis: An expanded sourcebook. Thousand Oaks, CA: Sage.

Mitchell, C. \& Sackney, L. (2000). Profound improvement: Building capacity for a learning community. Lisse, The Netherlands: Swets \& Zeitlinger.

National Councils of Teachers of English (2010). Teachers learning communities. Research based recommendations for establishing teacher learning communities. Urbana, ILL: The Council Chronicle.

Peterson, K.D. (2002). Positive or negative?. Journal of Staff Development, 23(3), 10-15.

Peterson, R. (1992). Life in a crowded place: Making a learning community. Portsmouth, NH: Heinemann.

Phillips, J. (2003). Powerful learning: Creating learning communities in urban school reform. Journal of Curriculum and Supervision, 18(3), 240-25.

Richardson, V. (1998). How Teachers Change. Focus on basics: connecting research and teaching, $2(C)$. Retrieved October from http://www.ncsall.net/index.html@id=395.html

Roberts, S. M., \& Pruitt, E. Z. (2009). School as learning communities. Thousand Oaks, CA: Corwin Press.

Rockwell, E., \& Ezpeleta, J. (1987). La escuela: relato de un proceso de construcción inconcluso. Cuadernos de Investigación Educativa. México: DIE-CINVESTAV.

Rubin, H.J., \& Rubin, I. S. (2012). Qualitative Interviewing: The art of hearing data. Newsbury Park CA: Sage. 
142 M. Flores et al. - Building a Professional Learning Community

Sandelowski, M. (1995). Sample size in qualitative research. Research in Nursing \& Health, 18(2), 179-183. doi: 10.1002/nur.4770180211

Sarason, S. (1990). The predictable failure of educational reform. San Francisco, CA: Jossey-Bass.

Senge, P. (1990). The fifth discipline: The art and practice of the learning organization. New York, NY: Doubleday.

Senge, P., Cambron-McCabe, N., Lucas, T., Smith, B., Dutton, J., \& Kleiner, A. (2000). Schools that learn. New York, NY: Doubleday.

Sergiovanni, T. (1994). Building community in schools. San Francisco, CA: Jossey Bass.

Skalicky, J., and West, M. (2008). UTAS Community of practice initiative. Centre for the Advancement of Learning and Teaching.

Spradley, J.A. (1979). Participant observation. Belmont, CA: Cengage Learning.

Stake, R. (2006). Multiple case study analysis. New York: The Guilford Press.

Stoll, L., Bollam, R., McMahon, A., Wallace, M., \& Thomas, S. (2006). Professional learning communities a review of the literature. Journal of Educational Change. 7, 221-258. doi: 10.1007/s10833-006-0001-8

Stoll, L. \& Fink, D. (1996). Changing our schools: Linking School Effectiveness and School Improvement. Buckingham: Open University Press.

Toole, J.C. \& Louis, K.S. (2002). The role of professional learning communities in international education. In K. Leithwood \& P. Hallinger. (Eds), Second international handbook of educational leadership and administration. Dordrecht: Kluwer.doi: 10.1007/978-94-010-0375-9_10

Wenger, E. (2001). Communities of Practice: Learning, meaning, and identity (Learning in doing: social, cognitive and computational perspectives). New York: Cambridge University Press.

Wenger, E., McDermott, and Snyder, W. M. (2002). Cultivating communities of practice. Boston, MA: Harvard Business School Press

Wolcott, H.F. (1997). Ethnographic research in education. In R.M. Jaeger (Ed.), Complementary Methods for Research in Education (pp. 327353).Washington, D.C: American Educational Research Association.

Zepeda, S. (2004). Leadership to Build Learning Communities. The Educational Forum, 68(2), 144-15. doi: 10.1080/00131720408984621 
Manuel Flores Fahara is a faculty member at the School of Education, Humanities and Social Sciences from Tecnológico de Monterrey, Mexico.

Contact Address: manuel.flores@itesm.mx 